\title{
Perbedaan Sumber Protein Ransum Menghasilkan Fermentasi Rumen yang Efisien
}

\section{(Difference of Feed Protein Sources to Produce Efficient Rumen Fermentation)}

\author{
Puastuti W, Yulistiani D \\ Balai Penelitian Ternak Jl. Veteran III Banjarwaru Ciawi Bogor, PO Box 221, Bogor 16720 \\ wisri_puast@yahoo.com
}

\begin{abstract}
Feed efficiency can be seen from the aspect of production compared to the feed input or from the digestion process of the feed itself. The study aimed to evaluate the effect of rations with different protein sources on rumen fermentation in order to improve feed efficiency. The diet consists of $40 \%$ grass and $60 \%$ concentrate contained $18.6 \%$ crude protein and 2.906 $\mathrm{kcal} / \mathrm{kg}$ ME (metabolizable energy). There were 4 experimental rations, namely RBK (contained soybean meal); RBIS (contained palm kernel meal); RDG (contained gamal/Gliricidia leaves); RDK (contained Caliandra leaves). Evaluation of in vitro digestibility was carried out for 48 hours incubation. The experiment was conducted using a completely randomized design which was repeated 8 times. The difference of protein sources in the ration did not cause differences $(\mathrm{P}>0.05)$ in $\mathrm{DM}$ and $\mathrm{OM}$ digestibility. The rumen bacteria population of the four rations was not significantly different $(\mathrm{P}>0.05)$, but the highest protozoa of $17.94 \times 10^{5}$ cells $/ \mathrm{ml}$ was produced from the RBK ration and the lowest $5.63 \times 10^{5}$ cells/ml was produced from RDK rations. RDK ration produced lower VFA and $\mathrm{C} 2(\mathrm{P}<0.05)$ than RBK, RBIS and RDG, but similar for C3, C4 and C5. Total gas production between the four rations is relatively similar $(\mathrm{P}>0.05)$. Methane gas production from RBK ration was higher $(\mathrm{P}<0.05)$ than RBIS, RDG and RDK. Methane gas calculated per gram of digestible $\mathrm{OM}$ shows no significant difference $(\mathrm{P}>0.05)$ with an average of $111.56-121.84 \mathrm{ml} / \mathrm{g}$. It can be concluded that differences in protein sources produce similar digestibility, but produce different fermentation products. The most potential source of BIS protein is providing energy and efficient digestion.
\end{abstract}

Key words: Protein, rumen fermentation, feed efficiency, methane emission

\begin{abstract}
ABSTRAK
Efisiensi penggunaan pakan dapat dilihat dari aspek produksi dibandingkan dengan input pakannya atau ditinjau dari proses pencernaan pakan itu sendiri. Penelitian bertujuan mengevaluasi ransum dengan sumber protein berbeda terhadap fermentasi rumen untuk meningkatkan efisiensi penggunaan pakan. Ransum terdiri dari $40 \%$ rumput dan $60 \%$ konsentrat dengan kadar protein 18,6\% dan energi $2.906 \mathrm{kkal} / \mathrm{kg} \mathrm{ME}$. Terdapat 4 ransum percobaan yaitu RBK = mengandung bungkil kedelai; RBIS = mengandung bungkil inti sawit; $\mathrm{RDG}=$ mengandung daun gamal; $\mathrm{RDK}=$ mengandung daun kaliandra. Kecernaan fermentasi in vitro dilakukan selama 48 jam. Percobaan dilakukan menggunakan rancangan acak lengkap dengan ulangan sebanyak 8 kali. Perbedaan sumber protein ransum tidak menyebabkan perbedaan $(\mathrm{P}>0,05)$ nilai kecernaan $\mathrm{BK}$ dan $\mathrm{BO}$. Populasi bakteri rumen diantara keempat ransum tidak ada perbedaan $(\mathrm{P}>0,05)$, namun protozoa tertinggi $17,94 \times 10^{5} \mathrm{sel} / \mathrm{ml}$ dihasilkan dari ransum RBK dan paling rendah 5,63 x $10^{5} \mathrm{sel} / \mathrm{ml}$ dihasilkan dari ransum RDK. Ransum RDK menghasilkan VFA dan $\mathrm{C} 2$ lebih rendah $(\mathrm{P}<0,05)$ dibanding RBK, RBIS dan RDG,
\end{abstract}


namun serupa untuk C3, C4 dan C5. Produksi gas total diantara keempat ransum relatif sama $(\mathrm{P}>0,05)$. Produksi gas metana ransum RBK lebih tinggi $(\mathrm{P}<0,05)$ dibandingkan RBIS, RDG dan RDK. Gas metana dihitung setiap gram BO tercerna menunjukkan tidak berbeda nyata (P>0,05) dengan rata-rata 111,56 -121,84 ml/g. Dapat disimpulkan bahwa perbedaan sumber protein menghasilkan kecernaan yang serupa, namun menghasilkan produk fermentasi yang berbeda. Sumber protein BIS paling potensial dalam menyediakan energi dan efisien dalam pencernaan ransum.

Kata kunci: Protein, fermentasi rumen, efisiensi pakan, emisi metana

\section{PENDAHULUAN}

Pemanfaatan nutrien dari pakan untuk memenuhi kebutuhan hidup pokok dan mendukung produksi menentukan tingkat efisiensinya. Ternak yang memiliki produksi tinggi belum tentu efisien dalam pemanfaatan pakan, sehingga dari aspek ekonomi juga belum tentu menguntungkan. Efisiensi penggunaan pakan dapat dilihat dari aspek produksi dibandingkan dengan input pakannya. Selain itu efisiensi penggunaan pakan juga dapat ditinjau dari proses pencernaan pakan itu sendiri. Pada ternak ruminansia selain proses pencernaan secara enzimatis di dalam usus, terjadi juga proses pencernaan secara fermentasi di dalam rumen yang menghasilkan energi dalam bentuk Volatile Fatty Acid (VFA) dan protein mikroba. Selain VFA juga dihasilkan gas metana yang dikeluarkan dalam rangka menjaga kondisi rumen tetap normal. Semakin banyak produksi gas metana yang dihasilkan untuk setiap gram bahan organik yang tercerna maka semakin tidak efisien dalam memanfaatkan pakan.

Gas metana dihasilkan dalam proses pemanfaatan energi pakan pada ternak ruminansia. Gas metana yang diemisikan oleh ternak ruminansia merupakan hasil dari fermentasi pakan di dalam rumen, yang dipengaruhi oleh faktor pakan dan daya cerna pakan. Emisi gas metana enterik berasal dari pencernaan pakan serat secara fermentasi di dalam rumen selanjutnya dikeluarkan melalui eruktasi (sekitar 83\%), pernapasan (sekitar $16 \%$ ) dan anus (sekitar 1\%) (Vlaming 2008). Menurut Shibata \& Terada (2010) efisiensi pemanfaatan energi pakan tergantung pada jenis hewan, jenis atau kualitas dan kuantitas pakan, kondisi lingkungan, dan sebagainya. Emisi gas metana sangat mempengaruhi efisiensi ternak dalam memanfaatkan energi pakan karena emisi gas metana menggunakan 2-12\% energi yang dikonsumsi sehingga akan berpengaruh pada efisiensi produksi tenak. Bila dipandang dari sisi mikroba rumen, produksi gas metana memiliki nilai kehidupan, sedangkan dipandang dari sisi efisiensi penggunaan energi, produksi gas metana merupakan pemborosan dan merugikan bagi ternak. Emisi gas metana merupakan salah satu bentuk kehilangan energi dari pakan yang dikonsumsi dan berkontribusi terhadap pemanasan global dari aspek lingkungan. Dalam hal ini perlu dicari cara untuk menurunkan emisi gas metana tanpa mengabaikan produksi.

Manipulasi ekosistem mikroba rumen untuk meningkatkan kecernaan serat, menurunkan emisi gas metana dan ekskresi nitrogen untuk meningkatkan penggunaan pakan menjadi salah satu tujuan dari ahli pakan (Patra et al. 2006). Tipe dari pakan berpotensi memodifikasi fermentasi rumen dan dapat menjadi salah satu strategi untuk menurunkan populasi protozoa dan metanogen sehingga meningkatkan efisiensi penggunaan pakan pada ruminansia (Anantasook \& Wanapat 2012). Sebagai contoh pada saat rasio konsentrat dalam pakan ditingkatkan produksi gas metana menurun karena hidrogen dari metana digunakan untuk menghasilkan propionat (Poungchompu et al. 2009). Selain itu pemberian pakan mengandung tanin, saponin dan lemak/minyak dilaporkan dapat menurunkan emisi gas metana (Jayanegara et al. 2012; Toprak 2015; 
Shibata \& Terada 2010). Tanin dan saponin banyak terdapat pada bahan pakan sumber protein seperti kaliandra, gliricidia, lamtoro, dan albizia. Penambahan lemak ke dalam ransum ruminansia menjadi cara yang efisien dan mudah untuk mengurangi produksi metana. Namun demikian harus mempertimbangkan aspek kecernaan pakan serat. Lemak pakan di dalam rumen dapat mempengaruhi kehidupan mikroba rumen, terutama bakteri karena tidak mempunyai kemampuan lipolisis. Berbeda dengan hasil penelitian bahwa asam lemak tak jenuh (terutama asam linoleat) meningkatkan jumlah protozoa ciliata dan mempengaruhi pencernaan selulosa dan kualitas susu dengan meningkatkan jumlah bakteri selulolitik (Ivan et al. 2013). Sebuah studi yang dilakukan pada kambing menunjukkan bahwa bahan pakan dengan kadar lemak tinggi seperti solid decanter dan bungkil inti sawit dapat digunakan dalam diet kambing dan berpengaruh pada daya cerna serat namun tidak menurunkan jumlah protozoa rumen (Abubakr et al. 2013).

Berdasarkan telaah literatur tersebut maka penelitian bertujuan mengevaluasi ransum dengan sumber protein berbeda terhadap fermentasi rumen untuk meningkatkan efisiensi penggunaan pakan.

\section{MATERI DAN METODE}

\section{Ranasum percobaan}

Empat sumber protein yaitu bungkil kedelai, bungkil inti sawit, tepung daun gamal dan daun kaliandra digunakan sebagai sumber protein ransum perlakuan. Ransum terdiri dari $40 \%$ rumput dan 60\% konsentrat dengan kadar protein 18,6\% dan energi 2.906 $\mathrm{kkal} / \mathrm{kg}$ ME. Terdapat 4 ransum percobaan dengan sumber protein berbeda yaitu RBK = ransum mengandung bungkil kedelai; RBIS = ransum mengandung bungkil inti sawit; $\mathrm{RDG}=$ ransum mengandung daun gamal; RDK = ransum mengandung daun kaliandra. Susunan ransum percobaan selengkapnya disajikan pada Tabel 1 .

Tabel 1. Formula ransum percobaan in vitro

\begin{tabular}{lllll}
\hline \hline Pakan (\%) & RBK & RBIS & RDG & RDK \\
\hline Rumput gajah (40\%): & 40,0 & 40,0 & 40,0 & 40,0 \\
Konsentrat (60\%): & & & & \\
Dedak & 22,2 & 3,0 & 4,8 & 4,8 \\
Jagung & 16,8 & 6,0 & 8,4 & 9,6 \\
Pollard & 2,4 & 16,8 & 13,8 & 13,2 \\
Ampas tahu & 9,0 & 9,0 & 9,0 & 9,0 \\
Bungkil kedelai & 9,0 & 0,0 & 0,0 & 0,0 \\
BIS & 0,0 & 24,3 & 0,0 & 0,0 \\
Daun gamal & 0,0 & 0,0 & 23,1 & 0,0 \\
Daun kaliandra & 0,0 & 0,0 & 0,0 & 22,5 \\
Mineral mix & 0,6 & 0,6 & 0,6 & 0,6 \\
Urea & 0,0 & 0,3 & 0,3 & 0,3 \\
\hline
\end{tabular}

Percobaan kecernaan fermentasi in vitro dilakukan selama 48 jam (metode Menke \& Steingass 1988; Blummel et al. 1997). Digunakan cairan rumen dari domba dewasa yang 
diberi pakan standar rumput gajah dan konsentrat. Cairan rumen diambil di pagi hari menggunakan stomach tube.

Parameter yang diukur meliputi degradasi bahan kering dan bahan organik, $\mathrm{pH}$ cairan rumen, kadar NH3, populasi mikroba rumen dan VFA parsial. pH cairan rumen diukur dengan $\mathrm{pH}$ meter, kadar NH3 berdasarkan mikrodifusi Conwey (Department Of Dairy Science 1969), populasi mikroba dihitung berdasarkan metode Ogimoto \& Imai (1981) serta VFA diukur dengan Gas Chromatography. Komposisi produksi gas CO2 dan CH4 dianalisis menurut prosedur Thalib (2004). Prosedur mencakup penampungan gas hasil fermentasi dengan siring pengukur volume. Dengan sistem konektor T, gas dalam siring tersebut diinjeksikan ke dalam 2 tabung yang dihubungkan secara serial dan keduanya berisi larutan $\mathrm{NaOH} 6 \mathrm{~N}$ dan selanjutnya gas yang lepas ditampung dengan siring pengukur volume kedua untuk menampung gas $\mathrm{CH} 4$.

\section{Rancangan percobaan dan analisis data}

Pengujian keempat ransum dilakukan menggunakan rancangan acak lengkap yang diulang masing-masing 6 kali. Data yang diperoleh dianalisis menggunakan analisis variansi dan perbedaan diantara rataan perlakuan diuji Duncan. Data dianalisa dengan bantuan program SAS (2002).

\section{HASIL DAN PEMBAHASAN}

\section{Degradasi ransum dengan sumber protein berbeda (in vitro)}

Hasil uji degradasi bahan kering (BK) dan bahan organik (BO) in vitro disajikan pada Tabel 2. Perbedaan sumber protein ransum tidak menyebabkan perbedaan $(\mathrm{P}>0,05)$ nilai degradasi BK dan BO ransum. Nilai degradasi BK dan BO tertinggi dihasilkan dari ransum RBK menunjukkan lebih tinggi 4,96 dan 5,67\% dari ketiga ransum lainnya, namun secara statistik tidak berbeda nyata. Hal ini dikarenakan ransum disusun iso protein dan iso energi mengandung serat NDF antara 52,13-62,39\%. Hasil ini lebih tinggi dari nilai degradasi BK ransum berbahan ubi kayu dengan sumber protein daun gamal yaitu sebesar 51,07\% (Muchlas et al. 2014) maupun ransum pakan yang diberi tanin dan saponin sebesar 50,23-56,73\% (Wahyuni et al. 2014), namun lebih rendah bila dibandingkan dengan degradasi BK ransum komplit berbasis silase rumput yang diberi probiotik Bioplus yaitu 62,12- 65,51\% (Riswandi et al. 2015).

Tabel 2. Degradasi bahan kering dan organik dari ransum dengan sumber protein berbeda

\begin{tabular}{lcccc}
\hline \hline Ransum & RBK & RBIS & RDG & RDK \\
\hline Degradasi BK (\%) & $62,24 \pm 4,50$ & $58,42 \pm 3,83$ & $60,46 \pm 2,90$ & $58,57 \pm 5,40$ \\
Degradasi BO (\%) & $60,84 \pm 4,70$ & $56,56 \pm 3,64$ & $58,88 \pm 3,78$ & $56.74 \pm 6,33$ \\
\hline
\end{tabular}

Nilai dengan huruf berbeda pada baris yang sama menunjukkan berbeda nyata $(\mathrm{P}<0,05)$; RBK = ransum mengandung bungkil kedelai; RBIS = ransum mengandung bungkil inti sawit; $\mathrm{RDG}=$ ransum mengandung daun gamal $\mathrm{RDK}=$ ransum mengandung daun kaliandra

Nilai degradasi mencerminkan tingkat fermentabilitas pakan di dalam rumen yang berhubungan dengan populasi mikrobanya. Dengan kata lain bioproses rumen sangat dipengaruhi oleh populasi dan aktivitas mikroba rumen dan fermentabilitas pakan. Suplai 
energi dan protein yang cukup dan seimbang akan mengoptimalkan kondisi fermentasi dalam rumen. Keempat ransum memiliki tingkat degradasi yang serupa (Tabel 2) dengan perbedaan $(\mathrm{P}<0,05)$ pada populasi protozoa namun tidak berbeda pada populasi bakteri rumen $(\mathrm{P}>0,05)$. Keberadaan lemak dari BIS dan tanin dari kaliandra di dalam ransum diduga mempengaruhi populasi protozoa rumen. Dilaporkan kadar tanin dari kaliandra dan glirisidia masing-masing sebesar 19,5 dan 2,52\% dari bahan kering (Fadiyimu et al. 2011) dan kadar lemak dari BIS sebesar 11,93\%. Mikroba rumen dalam hal ini bakteri merupakan ujung tombak pencernaan makanan dalam rumen, semakin tinggi populasi bakteri dalam rumen semakin tinggi pula laju degradasi zat makanan dalam rumen (Elihasridas \& Herawati 2014). Keempat ransum menghasilkan populasi bakteri rumen serupa $(\mathrm{P}>0,05)$ antara 3,70 - 3,89 $\times 10^{9} \mathrm{kol} / \mathrm{ml}$, dan tidak menyebabkan perbedaan degradasi BK dan BO (Tabel 2).

Perbedaan sumber protein ransum menyebabkan perbedaan protozoa rumen, dimana populasi tertinggi $17,94 \times 10^{5} \mathrm{sel} / \mathrm{ml}$ dihasilkan dari ransum RBK, sedangkan populasi paling rendah $5,63 \times 10^{5} \mathrm{sel} / \mathrm{mldih}$ asilkan oleh ransum RDK. Protozoa untuk hidupnya memerlukan bahan pakan yang memiliki sumber energi dan protein mudah tersedia yang ditunjukkan pada ransum RBK dengan sumber protein bungkil kedelai. Sesuai pernyataan laju pertumbuhan mikroba maksimum dapat dicapai apabila pasokan semua nutrien yang diperlukan untuk pertumbuhan dan perkembangan mikroba tersedia dalam konsentrasi optimum (Elihasridas \& Herawati 2014). Produk $\mathrm{NH}_{3}$ merupakan salah satu hasil degradasi protein di dalam rumen yang digunakan sebagai sumber nitrogen utama untuk perkembangbiakan mikroba/bakteri rumen. Kandungan $\mathrm{NH}_{3}$ keempat ransum percobaan serupa $(\mathrm{P}>0,05)$, menunjukkan keempat ransum memiliki tingkat fermentasi yang sama (Tabel 3).

Tabel 3. Populasi bakteri total dan protozoa serta kadar NH3 dan $\mathrm{pH}$ rumen dari ransum dengan sumber protein berbeda

\begin{tabular}{lcccc}
\hline \hline Ransum & RBK & RBIS & RDG & RDK \\
\hline Bakteri $\left(10^{9} \mathrm{kol} / \mathrm{ml}\right)$ & $3,70 \pm 0,14$ & $3,89 \pm 0,33$ & $3,79 \pm 0,16$ & $3,79 \pm 0,18$ \\
Protozoa $\left(10^{5} \mathrm{sel} / \mathrm{ml}\right)$ & $17,94 \pm 1,35^{\mathrm{a}}$ & $8,44 \pm 0,83^{\mathrm{b}}$ & $7,44 \pm 0,48^{\mathrm{c}}$ & $5,63 \pm 0,60^{\mathrm{d}}$ \\
$\mathrm{pH}$ & $6,90 \pm 0,08^{\mathrm{bc}}$ & $7,00 \pm 0,00^{\mathrm{a}}$ & $6,88 \pm 0,10^{\mathrm{c}}$ & $6,95 \pm 0,06^{\mathrm{ab}}$ \\
$\mathrm{NH}_{3}(\mathrm{mM})$ & $10,79 \pm 0,19$ & $10,71 \pm 0,68$ & $10,86 \pm 0,22$ & $10,88 \pm 0,42$ \\
\hline
\end{tabular}

Nilai dengan huruf berbeda pada baris yang sama menunjukkan berbeda nyata $(\mathrm{P}<0,05)$

Hristov et al. (2004), melaporkan bahwa konsentrasi amonia rumen cenderung lebih tinggi pada ternak yang diberi pakan dengan protein mudah didegradasi dibandingkan dengan protein yang tahan degradasi. Ransum percobaan terdiri dari rumput dengan konsentrat yang mengandung protein $18,6 \%$. Nilai NH3 pada penelitian ini relatif tinggi dibandingkan dengan nilai yang sudah dilaporkan sebelumnya, yaitu ransum komplit berbasis limbah jagung amoniasi dengan kadar PK ransum 11-14\% menghasilkan NH3 antara 6,84-12,86 mg/100 ml (4,9-9,2 mM) cairan rumen (Elihasridas \& Herawati 2014). Fermentasi keempat ransum menunjukkan kondisi yang normal, dengan ditunjukkan oleh $\mathrm{pH}$ cairan rumen berkisar 6,8-7. Perbedaan terjadi pada RBK vs RBIS dan RBIS vs RDG. Keadaan ini sesuai dengan yang dilaporkan rumen Elihasridas \& Herawati (2014) bahwa $\mathrm{pH}$ rumen yang ideal untuk perkembangan mikroba rumen adalah 6,0-7,0. 


\section{Produk fermentasi rumen}

Produk fermentasi sumber energi (karbohidrat) oleh mikroba rumen berupa asam lemak volatile (VFA). Ransum RDK menghasilkan VFA lebih rendah $(\mathrm{P}<0,05)$ dibanding RBK, RBIS dan RDG (22,1 $\mathrm{mM}$ vs 33,1-39,3 mM). Nilai VFA dari ransum RDK memiliki perbedaan sebesar 49,8\% dibandingkan dengan RBK, sebesar 77,8\% dengan RBIS dan 71,9\% dengan RDG. Proporsi asam asetat (C2) untuk keempat ransum menyerupai VFA total dengan nilai terendah pada ransum RDK. Sementara untuk asam propionat (C3), asam butirat (C4) dan asam valerat (C5) menunjukkan tidak ada perbedaan untuk semua ransum. Tingginya nilai C2 menunjukkan tingkat fermentasi karbohidrat struktural yang tinggi pada ransum RBK, RBIS, dan RDG, sedangkan pada RDK karena adanya tanin dari kaliandra diduga mempengaruhi tingkat kecernaan serat. Sesuai pernyataan bahwa kuantitas protein dan jumlah protein mudah tercerna yang tersedia akan mengubah rasio karbohidrat terfermentasi atau secara langsung berhubungan dengan biomas mikroba (Dijkstra 1994; Widyobroto et al. 2007). Nilai VFA dan $\mathrm{C} 2$ yang lebih rendah berkaitan dengan populasi protozoa rumen (Tabel 3) dan juga rasio C2:C3 (Tabel 4). Rasio C2:C3 hanya berbeda pada ransum RDG vs RDK 3,7 vs 2,7. Ransum dengan potensi produksi C2 yang tinggi pada ternak perah akan dimanifestasikan pada produksi susu dan kadar lemak susu yang tinggi pula. Seperti yang dilaporkan oleh Ramadhan et al. (2013) bahwa kadar lemak susu sangat dipengaruhi oleh faktor-faktor yang mempengaruhi produksi asam asetat dalam rumen, dalam hal ini adalah kinerja mikroba rumen dalam memfermentasi serat kasar menjadi asam asetat.

Efisiensi produksi pada ternak juga dapat ditinjau dari emisi gas metananya yang merupakan indikasi banyaknya asupan energi dari pakan yang terbuang melalui pernafasan dan eruktasi pada ternak ruminansia.

Tabel 4. Produksi VFA total, proporsi asam lemak dan gas metana rumen

\begin{tabular}{lllll}
\hline \hline Ransum & RBK & RBIS & RDG & RDK \\
\hline VFA $(\mathrm{mM})$ & $33,1 \pm 4,3^{\mathrm{a}}$ & $39,3 \pm 2,5^{\mathrm{a}}$ & $38,0 \pm 7,7^{\mathrm{a}}$ & $22,1 \pm 4,6^{\mathrm{b}}$ \\
$\mathrm{C} 2(\%)$ & $64,1 \pm 4,2^{\mathrm{a}}$ & $65,5 \pm 2,6^{\mathrm{a}}$ & $67,7 \pm 4,1^{\mathrm{a}}$ & $60,5 \pm 2,9^{\mathrm{b}}$ \\
$\mathrm{C} 3(\%)$ & $20,9 \pm 1,8$ & $19,0 \pm 1,1$ & $18,7 \pm 1,7$ & $22,2 \pm 2,0$ \\
$\mathrm{C} 4(\%)$ & $11,4 \pm 1,9$ & $12,1 \pm 1,1$ & $10,3 \pm 1,8$ & $13,0 \pm 1,0$ \\
$\mathrm{C} 5(\%)$ & $3,6 \pm 0,6$ & $3,4 \pm 0,6$ & $3,4 \pm 0,8$ & $4,4 \pm 0,4$ \\
$\mathrm{C} 2: \mathrm{C} 3$ & $3,1 \pm 0,4^{\mathrm{bc}}$ & $3,5 \pm 0,3^{\mathrm{ab}}$ & $3,7 \pm 0,6^{\mathrm{a}}$ & $2,8 \pm 0,4^{\mathrm{c}}$ \\
$\mathrm{Gas}$ Total $(\mathrm{ml})$ & $86,4 \pm 1,5$ & $83,6 \pm 5,3$ & $83,8 \pm 1,8$ & $85,2 \pm 3,2$ \\
$\mathrm{CH}{ }_{4}(\mathrm{ml})$ & $33,9 \pm 1,1^{\mathrm{a}}$ & $30,1 \pm 0,5^{\mathrm{b}}$ & $30,4 \pm 1,01^{\mathrm{b}}$ & $31,0 \pm 1,2^{\mathrm{b}}$ \\
$\mathrm{CH}_{4}(\%)$ & $39,2 \pm 1,4^{\mathrm{a}}$ & $36,1 \pm 1,8^{\mathrm{b}}$ & $36,3 \pm 1,1^{\mathrm{b}}$ & $36,5 \pm 2,1^{\mathrm{b}}$ \\
$\mathrm{CH}_{4} / \mathrm{BO}(\mathrm{ml} / \mathrm{g})$ & $121,8 \pm 10,3$ & $114,3 \pm 6,0$ & $111,6 \pm 10,9$ & $120,6 \pm 17,7$ \\
\hline
\end{tabular}

Nilai dengan huruf berbeda pada baris yang sama menunjukkan berbeda nyata $(\mathrm{P}<0,05)$

Produksi gas total diantara keempat ransum relatif sama $(\mathrm{P}>0,05)$ namun dalam hal produksi gas metana ransum RBK lebih tinggi $(\mathrm{P}<0,05)$ dibandingkan $\mathrm{RBIS}, \mathrm{RDG}$ dan RDK. Ini menunjukkan sumber protein selain bungkil kedelai (RBK) menghasilkan emisi gas metana lebih rendah. Sumber protein BIS yang mengandung lemak 11,89\% tidak mempengaruhi kecernaan BK dan BO, justru bermanfaat menurunkan emisi gas metana. Selaras dengan adanya tannin dalam ransum RDK. Penambahan lemak $1 \%$ dalam 
konsentrat dapat menurunkan produksi metana di rumen sebesar 5,6\% (Beauchemin et al. 2007). Bila produksi gas metana dihitung untuk setiap gram BO tercerna menunjukkan tidak berbeda nyata $(\mathrm{P}>0,05)$ diantara keempat ransum yakni 111,56-121,84 $\mathrm{ml} \mathrm{CH}_{4}$ untuk setiap $1 \mathrm{~g}$ BO tercerna. Hal ini menunjukkan keempat ransum memiliki tingkat efisiensi yang sama. Bahan organik ransum yang dicerna menghasilkan VFA tertinggi dengan emisi gas metana paling rendah diharapkan akan menjadi ransum yang paling efisien untuk mendukung produksi pada ternak. Bannink et al. (2010) melaporkan terdapat hubungan linier antara konsumsi BK dan emisi gas metana pada sapi, karena semakin meningkat konsumsi BK akan meningkatkan fermentasi BO dan lebih lanjut akan meningkatkan produksi VFA dan gas fermentasi. Pada penelitian ini hubungan antara BO tercerna dengan emisi gas $\mathrm{CH} 4$ mengikuti persamaan $\mathrm{CH}_{4}(\mathrm{ml})=96,406 \mathrm{x}+$ $0,921, \mathrm{R}^{2}=0,3353$. Rendahnya $\mathrm{R}^{2}$ menggambarkan bahwa $\mathrm{BO}$ yang tercerna memiliki karakateristik yang beragam diantaranya adanya lemak ataupun tanin yang mempengaruhi daya cerna dan mikroba rumen. Berdasarkan parameter-parameter yang diukur dari kemampuan menghasilkan energi untuk mendukung produksi yang tinggi dan efisien dalam hal emisi gas metana, maka ransum RBIS dan RDG sangat potensial sebagai sumber protein ransum. Potensi BIS berlimpah dan tersedia sepanjang tahun sehingga penggunaan sumber protein BIS akan memberikan informasi baru dalam memanfaatkan ketersediaan sumber pakan lokal yang berlimpah.

\section{KESIMPULAN}

Berdasarkan hasil penelitian dan pembahasan dapat disimpulkan bahwa: 1) Perbedaan sumber protein menghasilkan kecernaan yang serupa, namun menghasilkan produk fermentasi yang berbeda. 2) Ransum RBIS paling potensial dalam menyediakan energi dan efisien dalam fermentasi rumen ditinjau dari emisi gas metana per unit bahan organik tercerna untuk mendukung produksi ternak ruminansia.

\section{DAFTAR PUSTAKA}

Abubakr AR, Alimon AR, Yaakub H, Abdullah N, Ivan M. 2013. Digestibility, rumen protozoa, and ruminal fermentation in goats receiving dietary palm oil by-products. $\mathrm{J}$ Saudi Soc Agric Sci. 12:147-154.

Anantasook N, Wanapat M. 2012. Influence of rain tree pod meal supplementation on rice straw based diets using in vitro gas fermentation technique. Asian-Aust J Anim Sci. 25:325-334.

Bannink A, Smits MCJ, Kebreab E, Mills JAN, Ellis JL, Klop A, France J, Dijkstra J. 2010. Simulating the effects of grassland management and grass ensiling on methane emission from lactating cows. J Agric Sci. 148:55-72.

Beauchemin KA, Mcginn SM, Petit HV. 2007. Methane abatement strategies for cattle: Lipid supplementation of diets. Can J Anim Sci. 87:431-440.

Blummel M, Steingass H, Becker K. 1997. The relationship between in vitro gas production, in vitromicrobial biomass yield and $15 \mathrm{~N}$ incorporation and itsimplications for the prediction of voluntary feed intake of roughages. Br J Nutr. 77:911-921.

Department of Dairy Science. 1969. General laboratory procedure. Madison (USA): University of Wisconsin.

Dijkstra J. 1994. Production and absorbsion of volatile fatty acids in the rumen. Livest Prod Sci. 39:61-69. 
Elihasridas, Herawati R. 2014. Kecernaan in-vitro ransum berbasis limbah jagung amoniasi dengan berbagai rasio konsentrat untuk ruminansia. J Peternakan Indonesia. 16:145-151.

Fadiyimu AA, Fajemisin AN, Alokan JA. 2011. Chemical composition of selected browse plants and their acceptability by West African Dwarf sheep. Livest Res Rural Develop. 23:2011.

Hristov AN, Etter RP, Ropp JK, Grandeen KL. 2004. Effect of dietary crude protein level and degradability on ruminal fermentation and nitrogen utilization in lactating dairy cows. $\mathrm{J}$ Anim Sci. 82:3219-3229.

Ivan M, Petit HV, Chiquette J, Wright ADG. 2013. Rumen fermentation and microbial population in lactating dairy cows receiving diets containing oilseeds rich in C-18 fatty acids. Br J Nutr. 109:1211-1218.

Jayanegara A, Leiber F, Kreuzer M. 2012. Meta-analysis of the relationship between dietary tannin level and methane formation in ruminants from in vivo and in vitro experiments. $\mathrm{J}$ Anim Physiol Anim Nutr. 96:365-375.

Menke KH, Steingass H. 1988. Estimation of the energetic feed value obtained from chemical analysis and in vitro gas production using rumen fluid. Anim Res Dev. 28:7-55.

Muchlas M, Kusmartono, Marjuki. 2014. Pengaruh penambahan daun pohon terhadap kadar VFA dan kecernaan secara in-vitro ransum berbasis ketela pohon. J Ilmu-Ilmu Peternakan. 24:8-19.

Ogimoto K, Imai S. 1981. Atlas of rumen microbiology. Tokyo (Jepang): JSSP.

Patra AK, Kamra DN, Agarwal N. 2006. Effect of plant extracts on in vitro methanogenesis, enzyme activities and fermentation of feed in rumen liquor of buffalo. Anim Feed Sci Technol. 128:276-291.

Poungchompu O, Wanapat M, Wachirapakorn C, Wanapat S, Cherdthong A. 2009. Manipulation of ruminal fermentation and methane production by dietary saponins and tannins from mangosteen peel and soapberry fruit. Arch Anim Nutr. 63:389-400.

Ramadhan BG, Suprayogi TH, Sustiyah A. 2013. Tampilan produksi susu dan kadar lemak susu kambing Peranakan Ettawa akibat pemberian pakan dengan imbangan hijauan dan konsentrat yang berbeda. Anim Agric J. 2:353-361.

Riswandi, Muhakka, Lehan M. 2015. Evaluasi nilai kecernaan secara in vitro ransum ternak sapi bali yang disuplementasi dengan probiotik bioplus. J Peternakan Sriwijaya. 4:35-46.

SAS. 2002. SAS/STAS guide for personal computer release 9.0 edition. Cary, North Caroline (USA): SAS Institute Inc.

Shibata M, Terada F. 2010. Factors affecting methane production and mitigation in ruminants. Riview. Anim Sci J. 81:2-10.

Thalib A. 2004. In vitro study of effectiveness of saponin from Sapindus rarak fruit as methanogenesis inhibitor on ruminal digestion system. JITV. 9:164-171.

Toprak NN. 2015. Do fats reduce methane emission by ruminants? A review. Anim Sci Papers Reports. 33:305-321.

Vlaming JB. 2008. Quantifying variation in estimated methane emission from ruminants using the SF6 tracer fechnique [Thesis]. [Palmerston North (New Zealand): Massey University.

Wahyuni IMD, Muktiani A, Christiyanto M. 2014. Kecernaan bahan kering dan bahan organik dan degradabilitas serat pada pakan yang disuplementasi tanin dan saponin. Agripet. 2:115-124. 
Widyobroto WP, Budhi SPS, Agus A. 2007. Pengaruh aras undegraded protein dan energi terhadap kinetik fermentasi rumen dan sintesis protein mikroba pada sapi. J Indones Trop Anim Agric. 32:194-200. 